\title{
DEFINING MATHEMATICAL FORMULAS WHEN DETERMINING COST OF EMPLOYEE TURNOVER IN ENTERPRISE
}

\author{
[Definování matematických vzorců při zjišt’ování nákladů u fluktuace \\ pracovníků v podniku]
}

\author{
Jiří Duda ${ }^{1}$, Lenka Žůrková $^{2}$ \\ ${ }^{I}$ Mendelova univerzita v Brně, Provozně ekonomická fakulta, Zemědělská 1, 61300 Brno \\ Email:jiri.duda@mendelu.cz \\ ${ }^{2}$ Mendelova univerzita v Brně, Provozně ekonomická fakulta, Zemědělská 1, 61300 Brno \\ Email:xzurkov1@node.mendelu.cz
}

\begin{abstract}
The aim of this paper is to establish a general methodology for calculating the costs incurred by employee turnover. The authors developed mathematical formulas enabling calculation of these costs that they can be used in the business sphere when identifying costs related to the employees turnover. The authors tried to identify costs resulting from the loss of an employee. Important factors in the costs of employee turnover also include the loss of knowledge and possibly also a loss of customers. Costs of lost employee and department productiveness represent an important part of the costs of employee turnover, as well. The paper deals with the identification of costs associated with advertising vacant job positions and selection of new employees. These expenses involve also costs of training and admission of a new employee. In case of employee turnover, the highest costs are associated with an initial low performance of a new employee. Overall costs associated with the employee turnover may be as much as 1.5 - fold higher than the average annual wage of the leaving employee.
\end{abstract}

Keywords: costs, employee turnover, mathematical formulas, methodology.

JEL classification: M54, C69

Doručeno redakci: 7.6.2013; Recenzováno: 21.6.2013; 14.6.2013; Schváleno k publikování: 16.6.2014

\section{Úvod}

Fluktuace zaměstnanců a její ř řšení je významnou součásti personální práce v podniku. Pojem fluktuace vychází z latinského fluctuare, jenž znamená houpat se, pohybovat se sem a tam. V kontextu personální práce $\mathrm{v}$ podniku lze tento pojem definovat jako pohyb zaměstnanců $\mathrm{z}$ a do podniku (Armstrong, 2007). Fluktuace zaměstnanců je podle mnohých autorů jako napřs. Milkovich a Boudreau (1993), Dvořáková (2004), Koubek (2007) nejčastěji definována jako odchod (ztráta) pracovníka z organizace resp. míru změny zaměstnanců během daného období. Reiß (2008), Shahnawaz (2009) chápou pojem fluktuace jako veškerý vnější pohyb zaměstnanců ve vztahu k organizaci.

Podle d'Ambrosové a kol. (2009) a Ongoriho (2007) je fluktuace zaměstnanců součástí mobility zaměstnanců, jako přirozený koloběh zaměstnanců mezi podniky a pracovními nabídkami. Z průzkumu HR Controlling 2007 společnosti PricewaterhouseCoopers (FinExpert, 2007) je mediánová hodnota celkové fluktuace v České republice 14,8\%, ale v některých společnostech dosahuje i hodnot kolem $25 \%$, což je výrazně více než míra, která je považována za doporučenou (5-10 \%). Branham (2009) doporučuje úroveň celkové roční fluktuace pracovníků v rozmezí cca $5-7 \%$. Vysoká fluktuace zaměstnanců je v podniku nežádoucí jev, protože sebou nese vysoké náklady. Saratoga Institute (Branham, 2009) odhaduje průměrné náklady ztráty jednoho zaměstnance ve výši jeho ročního platu. Bliss 
(2012) odhaduje průměrné náklady na odchod zaměstnance ve výši 150 \% jeho ročního príjmu.

Cílem předloženého př́íspěvku je vytvoření matematických vzorců pro výpočty nákladů vzniklé fluktuací zaměstnance, které mohou být nápomocny podnikatelské sféře při určování výše nákladů při fluktuaci zaměstnance. Bude vytvořena obecná metodika výpočtů nákladů fluktuace zaměstnance. Pro základní členění nákladů je využívána charakteristika od Blisse (2012). Tento prŕspěvek se zabývá identifikováním nákladů vzniklé jak odchodem zaměstnance, tak se bude také zabývat náklady na nábor a nástup nového zaměstnance tzn. identifikováním nákladů vzniklé inzercí volné pracovní pozice, př́ípravou a uskutečněním náboru a výběru zaměstnance. Nedílnou součástí nákladů jsou také náklady na zaškolení a nástup nového zaměstnance. Podnik musí počítat $\mathrm{s}$ náklady počáteční nedostatečné produktivity nového zaměstnance.

\section{Náklady vyvolané odchodem zaměstnance}

Při sledování nákladů vyvolaných odchodem zaměstnance je nezbytné rozlišovat, zda byl odchod zaměstnance plánovaný či nikoliv. Při neplánovaném odchodu zaměstnance musí podnik sledovat navíc náklady na předčasný odchod zaměstnance bez zajištění náhrady (viz dočasné nahrazení pracovního výkonu na neobsazené pracovní pozici). Oproti ostatním výše uvedeným nákladům nemusí být tyto náklady zahrnuty do výpočtu nákladů vyvolaných odchodem zaměstnance (fluktuací).

\section{Dočasné nahrazení pracovního výkonu na neobsazené pracovní pozici}

Při zjištování nákladů dočasného nahrazení je důležité měřit časové období od odchodu zaměstnance po nástup vybraného náhradníka na neobsazenou pracovní pozici. Přičemž platí, že náklady na fluktuaci zaměstnancủ jsou o to větší, o co delší dobu nebyla zajištěna náhrada za odcházejícího pracovníka.

Neobsazenou pracovní pozici můžeme pokrýt dvěma způsoby:

a) přesčasy stávajících zaměstnanců - náklady na pokrytí pracovního výkonu $\left(\mathrm{N}_{\mathrm{PV}}\right)$ se skládají $\mathrm{z}$ hrubé mzdy odcházejícího zaměstnance $\left(\mathrm{M}_{\mathrm{Z}}\right)$, př́íplatku za práci přesčas $(\mathrm{P}$, vyjádřený $\mathrm{v} \%$ ) a doby trvání naleznutí náhrady $(\mathrm{t})$,

$$
N_{P V}=M_{Z} \cdot(1+P) \cdot t
$$

b) najmutí dočasné pracovní síly - náklady na pokrytí pracovního výkonu $\left(\mathrm{N}_{\mathrm{PV}}\right)$ jsou rovny hrubé mzdě odcházejícího zaměstnance $\left(\mathrm{M}_{\mathrm{Z}}\right)$, době trvání naleznutí náhrady $(\mathrm{t})$, provizi agentuře práce $\left(\mathrm{P}_{\mathrm{A}}\right)$ a náklady na zaškolení dočasného zaměstnance $\left(\mathrm{N}_{\mathrm{ZDZ}}\right)$.

$$
N_{P V}=M_{Z} \cdot t+P_{A}+N_{Z D Z}
$$

Ztráta produktivity vzhledem $k$ míre pracovního výkonu na původní pozici odcházejícího zaměstnance

Pokud existuje časová prodleva mezi odchodem zaměstnance a nalezením náhradníka na uvolněnou pozici (do výpočtu nákladů je zahrnuto dočasné nahrazení pracovního výkonu), je nutné započítat náklady na ztrátu produktivity dvakrát - jedenkrát za dočasné nahrazení, jedenkrát za nového zaměstnance. Nižší produktivita práce u nového zaměstnance je podle Murtagha (2003) první čtyři týdny cca $25 \%$ produktivity zcela výkonného zaměstnance. $\mathrm{V}$ průběhu pátého až osmého týdne je udávána produktivita práce $50 \%$ a až po dvanácti týdnech dosáhne zaměstnanec $100 \%$ produktivity práce.

Tabulka 1 popisuje předpokládaný pracovní výkon vzhledem k míře zkušeností náhradníka při různých řešení situace. 
Tabulka 1: Ztráta produktivity v průběhu adaptačního procesu

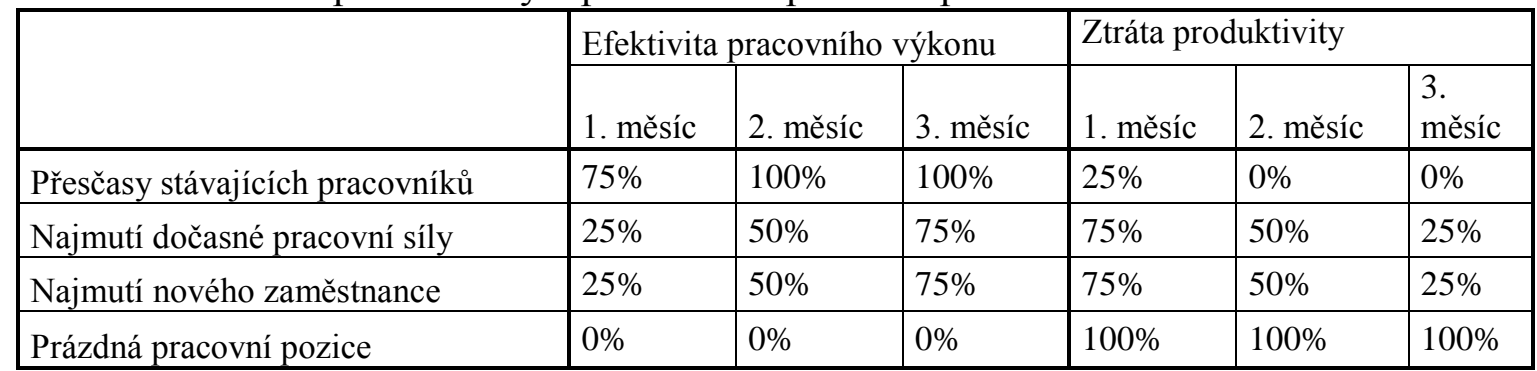

Zdroj: Murtagh (2003) upraveno autory

Náklady na ztrátu produktivity zaměstnance $\left(\mathrm{N}_{\mathrm{ZZ}}\right)$ jsou rovny průměrnému pracovnímu výkonu zaměstnance $\left(\mathrm{V}_{\mathrm{Z}}\right)$ násobenému procentuálním vyjádřením ztráty produktivity $(\mathrm{Z})$ podle fáze adaptačního procesu, dobou trvání naleznutí náhrady (t) a dobou trvání adaptačního procesu nového zaměstnance $\left(\mathrm{t}_{\mathrm{AP}}\right)$.

$$
N_{Z Z}=\left(V_{Z} \cdot Z \cdot t\right)+\left(V_{Z} \cdot Z \cdot t_{A P}\right)
$$

Průměrný pracovní výkon zaměstnance $\left(V_{Z}\right)$ je vypočítán $z$ přidané hodnoty $(H)$, kterou podnik za dané účetní období vytvořil, vztažené na jednoho pracovníka, tzn. přidaná hodnota dělená průměrným stavem zaměstnanců v podniku za období (S).

$$
V_{Z}=\frac{H}{S}
$$

\section{Ztráta produktivity oddělení jako celku}

Náklady na ztrátu produktivity celého oddělení $\left(\mathrm{N}_{\mathrm{ZO}}\right)$ budou vyčísleny pomocí průměrného pracovního výkonu oddělení $\left(\mathrm{V}_{\mathrm{O}}\right)$, koeficientu závislosti $(\mathrm{k})$ a doby trvání naleznutí náhrady (t). Opět je nutné započítat zde náklady na ztrátu produktivity dvakrát - jedenkrát za dočasné nahrazení, jedenkrát za nového zaměstnance, kdy ztráta produktivity po dobu adaptačního procesu je $50 \%$. Východiskem tvrzení je procentuální rozložení efektivity práce v průběhu adaptačního procesu ( 1 . měsíc $25 \%$, 2. měsíc $50 \%$, 3. měsíc $75 \%$ ).

$$
N_{\text {ZO }}=\left(V_{O} \cdot k \cdot t\right)+\left(V_{O} \cdot k \cdot t_{A P}\right) \cdot 50 \%
$$

Průměrný pracovní výkon oddělení $\left(\mathrm{V}_{\mathrm{O}}\right)$ lze určit pomocí přidané hodnotě $(\mathrm{H})$, kterou podnik za dané účetní období vytvořil, vztažené na celé oddělení. Přidaná hodnota dělená průměrným stavem zaměstnanců v podniku za období $(\mathrm{S})$ a násobená průměrným stavem pracovníků v sledovaném oddělení $\left(\mathrm{S}_{\mathrm{O}}\right)$.

$$
V_{o}=\frac{H}{S} \cdot S_{O}
$$

Koeficient závislosti (k) symbolizuje míru potřebnosti pracovního výkonu zaměstnance, na němž je závislá práce ostatních členů týmu. Koeficient závislosti (k) je vypočítán jako procentuální zastoupení odcházejícího pracovníka $\mathrm{v}$ oddělení $\left(1 / \mathrm{S}_{\mathrm{O}}\right)$ umocněné podílem rozdílu průměrného stavu pracovníků v oddělení $\left(\mathrm{S}_{\mathrm{O}}\right)$ sníženého o počet pracovníků prímo závislých na práci odcházejícího pracovníka (b, stanoveno subjektivně) a průměrného stavu pracovníků v sledovaném oddělení $\left(\mathrm{S}_{\mathrm{O}}\right)$.

$$
k=\left(\frac{1}{S_{O}}\right)^{\frac{S_{O}-b}{S_{O}}}
$$




\section{Čas manažera}

Dalším nákladem je čas manažera věnovaný na pochopení příčiny odchodu podřízeného a zaujmutí stanoviska $\mathrm{k}$ jeho vyřešení. Tento čas manažera se v nákladech na fluktuaci zaměstnanců projevuje formou mzdových nákladů manažera. Ve výpočtech nákladů na celkový čas manažera $\left(\mathrm{N}_{\mathrm{tM}}\right)$ bude zahrnut průměrný čas strávený výstupním pohovorem s odcházejícím zaměstnancem ( $\left.t_{\mathrm{VP}}\right)$, průměrný čas strávený diskuzí o příčinách a možných řešení s personalistou $\left(t_{D}\right)$, mzdový fond zaměstnanců $(M F)$ a hrubá mzda manažera $\left(M_{M}\right)$.

$$
N_{t M}=\frac{\left(t_{V P}+t_{D}\right)}{M F} \cdot M_{M}
$$

$\mathrm{V}$ př́padě zaměstnancovi výpovědi, by se měli manažeři zaměřit na příčiny odchodu zaměstnance. Podle Branhama (2009) manažeři uvádí, že hlavním důvodem fluktuace zaměstnanců jsou mzdy, popř. lepší konkurenční nabídka práce. Podobný názor uvádí Buchtová (2002) i Robinson (2008). Branham (2009) identifikoval více než 57 důvodů dobrovolné fluktuace, které shrnul do 7 přícin odchodů. Smith (2012) identifikoval deset nejčastějších příčin dobrovolné fluktuace.

\section{Provedení výstupního pohovoru, vypořádání a ukončení pracovního poměru}

Do nákladů na ukončení pracovního poměru $\left(\mathrm{N}_{\mathrm{UPP}}\right)$ bude započítán čas personalisty strávený výstupním pohovorem $\mathrm{s}$ odcházejícím zaměstnancem $\left(\mathrm{t}_{\mathrm{VP}}\right)$, čas placeného odcházejícího zaměstnance $\left(\mathrm{t}_{\mathrm{z}}\right)$, čas pro provedení papírové a elektronické formy administrace výstupu $\left(\mathrm{t}_{\mathrm{AV}}\right)$, jednorázové náklady na mzdové vypořádání $\left(\mathrm{N}_{\mathrm{MV}}\right)$, mzdový fond $(\mathrm{MF})$, hrubá mzda odcházejícího zaměstnance $\left(\mathrm{M}_{\mathrm{Z}}\right)$ a hrubá mzda personalisty $\left(\mathrm{M}_{\mathrm{P}}\right)$.

$$
N_{U P P}=\frac{\left(t_{V P}+t_{A V}\right)}{M F} \cdot M_{P}+\frac{t_{Z}}{M F} \cdot M_{Z}+N_{M V}
$$

Čas placeného odcházejícího zaměstnance $\left(\mathrm{t}_{\mathrm{z}}\right)$ se může skládat $\mathrm{z}$ času stráveného výstupním pohovorem, času stráveného získáním potvrzení o vypořádání závazků ve formě výstupního listu a času věnovanému podstoupení výstupní zdravotní prohlídky

Náklady na mzdové vypořádání $\left(\mathrm{N}_{\mathrm{MV}}\right)$ se skládají z průměrného odstupného $(\mathrm{O})$ a z průměrných prémií $(\mathrm{ZO})$, které byli zaměstnancům za rok vyplaceny, podělených průměrným stavem zaměstnanců v podniku za rok $(\mathrm{S})$.

$$
N_{M V}=\frac{O+Z O}{S}
$$

Nárok na odstupné má zaměstnanec, kterému skončil pracovní poměr výpovědí ze strany zaměstnavatele nebo dohodou pro organizační změny ve výši minimálně jedno až trojnásobku průměrného výdělku (Zákoník práce, 2012).

\section{Investice do vzdělávání a školení odcházejícího zaměstnance}

Náklady na investice do vzdělání a školení odcházejícího zaměstnance $\left(\mathrm{N}_{\mathrm{I}}\right)$ budou zjištěny pomocí podílu celkových ročních investic vynaložených na vzdělávání a školení zaměstnanců (I), průměrným stavem zaměstnanců v podniku za rok (S).

$$
N_{I}=\frac{I}{S}
$$

Ztráta vědomostí, dovedností a kontaktů odcházejícího zaměstnance

Náklady na ztrátu vědomostí, dovedností a kontaktů odcházejícího zaměstnance $\left(\mathrm{N}_{\mathrm{NH}}\right)$ budou měřeny vzhledem $\mathrm{k}$ roční hrubé mzdě odcházejícího zaměstnance $\left(\mathrm{M}_{\mathrm{Z}}\right)$ a počtu let, které zaměstnanec v organizaci strávil (T), kdy procentuální rozložení je přebráno z Blisse (2012).

$$
N_{N H}=50 \% \cdot M_{Z}+10 \% \cdot T \cdot M_{Z}
$$




\section{Náklady na nábor a výběr nového zaměstnance}

Druhou významnou kategorií identifikovaných nákladů jsou náklady na nábor a výběr nového zaměstnance. Do těchto nákladů se zařazují zejména náklady na inzerci, samotný výběr zaměstnance a náklady související se zaškolením zaměstnance.

\section{Inzerce volné pracovní pozice}

Inzerci v tisku podle poradenské společnosti HR-i (2012) lze vyčíslit na částku cca 20000 až 50000 Kč, v prípadě využití pracovní agentury se jedná o násobky měsíční mzdy zaměstnance. $V$ dnešní době se spíše využívá možností Internetu, např. u pracovního portálu www.profesia.cz (Profesia, 2012) jsou náklady za zveřejnění jedné pracovní pozice již cca od $1200 \mathrm{Kč} \mathrm{bez} \mathrm{DPH} \mathrm{za} 7$ dní. Podobné náklady na inzerci volné pracovní pozice jsou i na pracovním portálu www.sprace.cz (Sprace, 2012), kde náklady za zveřejnění jednoho pracovního inzerátu na měsíc jsou od $3500 \mathrm{Kč} \mathrm{bez} \mathrm{DPH.} \mathrm{Bliss} \mathrm{(2012)} \mathrm{uvádí} \mathrm{náklady}$ na inzerci od 200 do 500 dolarů.

Náklady na inzerování volné pracovní pozice $\left(\mathrm{N}_{\mathrm{INZ}}\right)$ budou vykalkulovány jako cena uveřejněné inzerce za den $\left(\mathrm{P}_{\mathrm{INZ}}\right)$ násobená průměrnou dobou doby trvání naleznutí náhrady $(\mathrm{t})$ a náklady na výtisk pro interní inzerci $\left(\mathrm{N}_{\mathrm{II}}\right)$ včetně stráveného času personalisty inzerováním $\left(\mathrm{t}_{\mathrm{I}}\right)$, mzdového fondu $(\mathrm{MF})$ a hrubé mzdy personalisty $\left(\mathrm{M}_{\mathrm{P}}\right)$.

$$
N_{I N Z}=P_{I N Z} \cdot t+N_{I I}+\frac{t_{I}}{M F} \cdot M_{P}
$$

\section{Čas personalisty na př́pravu a uskutečnění náboru}

Náklady na čas personalisty na př́ípravu a uskutečnění náboru $\left(\mathrm{N}_{P}\right)$ se skládají z času věnovanému zpracování požadavků na pracovní pozici, posuzování životopisů kandidátů, př́pravě a realizaci pohovorů, zpracování hodnocení kandidátů, ověřování referencí a oznamování výsledků o prijetí a neprrijetí, dále ze mzdového fondu (MF) a hrubé mzdy personalisty $\left(\mathrm{M}_{\mathrm{P}}\right)$. Součet časové dotace všech uvedených úkonů je označen jako doba př́pravy a uskutečnění náboru ( $\left.\mathrm{t}_{\mathrm{PUN}}\right)$. Bliss (2012) uvádí časové rozpětí zátěže asistenta personalisty na tyto operace na 20 a více hodin. Pokud se jedná o interní nábor, nevytváŕí se náklady u velké části př́pravných činností, ale je nutné započítat do nákladů čas, který uchazeč stráví pohovorem místo výkonu práce.

$$
N_{P}=\frac{t_{P U N}}{M F} \cdot M_{P}
$$

\section{Čas manažera strávený výběrem kandidáta}

Náklady na čas manažera strávený výběrem kandidáta $\left(\mathrm{N}_{\mathrm{tMK}}\right)$ je vypočítán pomocí času stráveného výběrem kandidáta $\left(t_{M K}\right)$, mzdového fondu $(M F)$ a hrubé mzdy manažera $\left(M_{M}\right)$. Bliss (2012) uvádí časové rozpětí zátěže personalisty při výběru až 100 hodin. Poradenská společnost HR-i (2012) vyčíslila náklady na přípravu výběrového řízení na 20 - 30000 Kč.

$$
N_{t M K}=\frac{t_{M K}}{M F} \cdot M_{M}
$$

\section{Zajištěni občerstveni při pohovorech}

Vynaložené náklady na občerstvení v průběhu pohovorů $\left(\mathrm{N}_{\mathrm{O}}\right)$ budou vypočítány $\mathrm{z}$ ceny poskytnutého občerstvení $\left(\mathrm{P}_{\mathrm{O}}\right)$, průměrného počtu kandidátů pozvaných k výběrovému řízení $\left(\mathrm{n}_{\mathrm{K}}\right)$ a počtu uskutečněných kol výběrového řízení $\left(\mathrm{n}_{\mathrm{V} \breve{R}}\right)$.

$$
N_{O}=P_{O} \cdot n_{K} \cdot n_{V \check{R}}
$$


Ověrování a testování uchazečů

Náklady na ověřování a testování uchazečů $\left(\mathrm{N}_{U}\right)$ se skládá z ceny služby za ověření a testování $\left(\mathrm{P}_{\mathrm{S}}\right)$ a průměrného počtu kandidátů pozvaných k výběrovému řízení $\left(\mathrm{n}_{\mathrm{K}}\right)$. Mezi př́íklady testování lze uvést například drogové testy (mezi něž patří testy moči, vlasů, krevní testy a testy slin), případná kriminální minulost, využití assessment centra. Mnozí autoři DeCenzo (1999), Hroník (2002), Dvořáková (2007) doporučují při výběru zaměstnance

i přes vy̌šsí náklady využití assessment centra.

$$
N_{U}=P_{S} \cdot n_{K}
$$

\section{Nástup a orientace nového zaměstnance}

Náklady na nástup a orientaci nového zaměstnance $\left(\mathrm{N}_{\mathrm{NO}}\right)$ jsou dány časem nového zaměstnance $\left(t_{N Z}\right)$, časem personalisty $\left(t_{P}\right)$, mzdovým fondem $(M F)$, hrubou mzdou zaměstnance $\left(\mathrm{M}_{\mathrm{Z}}\right)$ a hrubou mzdou personalisty $\left(\mathrm{M}_{\mathrm{P}}\right)$. Medián základní hodinové mzdy bez př́platků a odměn pro personalisty se v České republice pohybuje od 102 korun $(7,4 \$)$ na pozici personálního referenta do 149 korun $(10,7$ \$) na pozici manažera personálního oddělení (Martišková, 2012). Náklady na nástup nového zaměstnance vyčíslila poradenské společnost HR-i (2012) cca na 8000 - 12000 Kč.

$$
N_{N O}=\frac{t_{N Z}}{M F} \cdot M_{Z}+\frac{t_{P}}{M F} \cdot M_{P}
$$

\section{Nástupní administrace}

Náklady administrace na zavedení pracovníka do personálního informačního systému v papírové i elektronické verzi $\left(\mathrm{N}_{\mathrm{NA}}\right)$ jsou tvořeny časem personalisty $\left(\mathrm{t}_{\mathrm{AN}}\right)$, mzdovým fondem (MF) a hrubou mzdou personalisty $\left(\mathrm{M}_{\mathrm{P}}\right)$.

$$
N_{N A}=\frac{t_{A N}}{M F} \cdot M_{P}
$$

\section{Zaškolení na pracovišti}

Náklady na zaškolení nového zaměstnance na pracovišti $\left(\mathrm{N}_{\mathrm{Z}}\right)$ tvoři 50 \% z tříměsíční hrubé mzdy nového zaměstnance $\left(\mathrm{M}_{\mathrm{Z}}\right)$, čas manažera $\left(\mathrm{t}_{\mathrm{M}}\right)$, čas jeho kolegů $\left(\mathrm{t}_{\mathrm{K}}\right)$, hrubá mzda manažera $\left(\mathrm{M}_{\mathrm{M}}\right)$ a mzdový fond $(\mathrm{MF})$. Východiskem tvrzení je procentuální rozložení efektivity práce (Murtagh, 2003) v průběhu adaptačního procesu (1. měsíc $25 \%$, 2. měsíc 50 \%, 3. měsíc $75 \%$ ), to znamená, že náklady na proces učení zaujímají zbylou část do $100 \%$.

$$
N_{Z}=50 \% \cdot\left(3 \cdot M_{Z}\right)+\frac{t_{M}}{M F} \cdot M_{M}+\frac{t_{K}}{M F} \cdot M_{Z}
$$

\section{Materiál potřebný k zaškolení}

Náklady na materiál potřebný k zaškolení pracovníka $\left(\mathrm{N}_{\mathrm{M}}\right)$ jsou rovny ceně poskytnutých podkladů ke školení, manuálů, psacích potřeb, bločku aj. ( $\left.\mathrm{P}_{\text {ŠM }}\right)$.

$$
N_{M}=P_{\check{S} M}
$$

\section{Snižená produktivita nového zaměstnance}

Při nástupu nového zaměstnance je potřeba si uvědomit, že jeho produktivita práce nebude z počátku vysoká. Nižší produktivita práce u nového zaměstnance je podle Murtagha (2003) první čtyři týdny cca $25 \%$ produktivity zcela výkonného zaměstnance. V průběhu pátého až osmého týdne je udávána produktivita práce $50 \%$ a až po dvanácti týdnech dosáhne zaměstnanec $100 \%$ produktivity práce. 


\section{Závěr}

Fluktuace zaměstnanců je častým a trvalým problémem mnoha podniků. Vysoká fluktuace zaměstnanců je v podniku nežádoucí jev. Nejedná se pouze o odchod zkušených zaměstnanců, ale také o prŕíchod pracovníků nových, kteří potřebují čas, aby si osvojili procesy v podniku. Fluktuace pracovníků vytváŕí mnohé náklady pro podnik a tyto náklady mohou dosahovat výše několika desítek tisíc Kč. Cílem př́spěvku bylo vytvoření matematických vzorců pro výpočty nákladů vzniklé fluktuací zaměstnance. Do nákladů vyvolaných fluktuací byly zařazeny náklady na dočasné nahrazení pracovního výkonu na neobsazené pozici, na provedení výstupního pohovoru a ukončení pracovního poměru, ztráty znalostí odcházejícího zaměstnance. Rovněž byly určeny náklady na čas manažera na pochopení příčiny odchodu a náklady vynaložené na vzdělávání odcházejícího zaměstnance. Významnou část nákladů spojených s fluktuací tvoří také náklady vzniklé inzercí volné pracovní pozice, př́ípravou a uskutečněním náboru a výběru zaměstnance. Mezi identifikované náklady jsou také náklady na zaškolení a nástup nového zaměstnance. Nejvyšším nákladem při fluktuaci zaměstnance je počáteční nedostatečná produktivita nového zaměstnance, ztráta produktivity daného oddělení, kde došlo k fluktuaci zaměstnance. Celkové náklady fluktuace pracovníka mohou dosáhnout jeden až 1,5 násobek průměrné roční mzdy pracovníka.

\section{Literatura}

[1] d'AMBROSOVÁ, H., H. ČORNEJOVÁ a jiní, 2009. ABECEDA personalisty. 3. vyd. Olomouc: ANAG, spol. s r. o. 381 s. ISBN 978-80-7263-512-2.

[2] ARMSTRONG, M., 2007. Řizení lidských zdrojů. 10. vyd. Praha: Grada Publishing, a. s.. 800 s. ISBN 978-80-247-1407-3.

[3] BLISS, W. G., 2012. Cost of Employee Turnover [online]. Poslední revize 2012-01-14 [vid. 2012-10-05]. Dostupné z: http://www.isquare.com/turnover.cfm

[4] BRANHAM, L., 2009. 7 skrytých di̊vodi̊, proč zaměstnanci odcházejí z firem. Praha: Grada Publishing, a. s., 256 s. ISBN 978-80-247-2903-9.

[5] DECENZO, D. A. and S. P. ROBBINS, 1999. Human resource management. 6. vyd. New York: John Wiley \& Sons, 546 s. ISBN 0-471-29989-8.

[6] DVOŘÁKOVÁ, Z. a kol., 2007. Management lidských zdrojů. 1. vyd. Praha: C. H. BECK, 485 s. ISBN 978-80-7179-893-4.

[7] DVOŘÁKOVÁ, Z. a kol., 2004. Slovník pojmů k řizení lidských zdrojů. 1. vyd. Praha: C. H. BECK, 157 s. ISBN 80-7179-468-6.

[8] FINEXPERT, 2007. Společnostem v Česku se nedaři snižovat vysokou fluktuaci zaměstnancü. [online]. 2007. [vid. 2013-02-15]. Dostupné z: <http://finexpert.e15.cz/spolecnostem-v-cesku-se-nedari-snizovat-vysokoufluktuacizamestnancu_1>.

[9] HR-i, 2012. Vite kolik stojí ziskání a zapracování nového zaměstnance? [online]. 2012. [vid. 2013-01-18]. Dostupné z: http://www.hr-i.cz/aktuality/trapi-vas-vysoka-fluktuacezamestnancu.htm

[10] HRONÍK, F., 2002. Poznejte své zaměstnance, vše o assessment centre. 1. vyd. Brno: ERA, 370 s. ISBN 80-86517-20-9

[11] KOUBEK, J., 2007. Řizení lidských zdrojů: základy moderní personalistiky. 4. vyd. Praha: Management Press, 399 s. ISBN 978-80-7261-168-3. 
[12] MARTIŠKOVÁ, M., 2012. Čeští personalisté si za svou hodinovou mzdu mohou koupit dva BigMac hamburgery. [online]. [vid. 2012-10-26]. Dostupný z: http://mujplat.idnes.cz/hlavni-stranka/news/mujplat.cz-news/cesti-personaliste-si-zasvou-hodinovou-mzdu-mohou-koupit-dva-bigmac-hamburgery

[13] MILKOVICH, G. T. a J. W. BOUDREAU, 1993. Řizení lidských zdrojů. Praha: Grada a. s., 936 s. ISBN 80-85623-29-3.

[14] MURTAGH, J., 2003. The High Cost of Employee turnover [online]. [vid. 2012-10-05]. Dostupné z: http://www.thedreamspeaker.com/the-high-cost-of-employee-turnover/

[15] ONGORI, H., 2007. A review of the literature on employee turnover [online]. [vid. 201203-16]. Dostupné z:http://www.academicjournals.org/AJBM/ pdf/pdf2007/jun/ongori.pdf

[16] PROFESIA, 2012. Ceník služeb. [online]. [vid. 2012-10-05]. Dostupné z: http://www.profesia.cz/cms/o-nas/sluzby/cenik-sluzeb/41389?show=for_company

[17] REIß, CH., 2008. Fluktuation. [online]. [vid. 2012-09-20]. Dostupné z: http://www.personaler-online.de/typo3/nc/personalthemen/suche-in-artikeln/ detailansicht/artikel/fluktuation.html

[18] SHAHNAWAZ, M. G. a H. JAFRI, 2009. Job attitudes as predictor of employee turnover among stayers and leavers/hoppers. Journal of Management Research, 9(3), 159-166. ISSN 0972-5814.

[19] SPRACE, 2012. Ceník inzerce. [online]. [vid. 2012-10-05]. Dostupné z:. http://www.sprace.cz/zamestnavatel/ceniky.html 